\title{
HUBUNGAN ANTARA TINGKAT PENGETAHUAN, STATUS EKONOMI DAN KEBIASAAN MEROKOK DENGAN KEJADIAN TUBERKULOSIS PARU PADA ORANG DEWASA DI WILAYAH KERJA PUSKESMAS TUAN-TUAN KABUPATEN KETAPANG KALIMANTAN BARAT
}

\author{
Sri Marisya Setiarni, Adi Heru Sutomo, Widodo Hariyono \\ Fakultas Kesehatan Masyarakat, Universitas Ahmad Dahlan, Yogyakarta
}

\begin{abstract}
Background: Lung tuberculosis still be the health public problem at developing countries whole the world. Indonesia occupies sequence to 3 in world in the tuberculosis case after Chinese and India. Lung tuberculosis is also one of health public problem in Kabupaten Ketapang especially in Puskesmas Tuan-Tuan region. Problem causing of lung tuberculosis disease in this Puskesmas Tuan-Tuan hardly multi factor like still low public economics social level, the height of smoking habit level and the lack of knowledge about lung tuberculosis. The aim of this research find out the relationship between knowledge level, economic status and smoking habit with lung tuberculosis case at adult in Puskesmas Tuan-Tuan Kabupaten Ketapang Kalimantan Barat region.

Method: This research was observational research using cross sectional design. There was 84 respondent. Data analysis conduct by frequency distribution, bivariate analysis applies Chi Square and multivariate analysis with logistics regression.

Result: Result of this research indicates that from the variable knowledge level, economic status and smoking habit show there are relationship with lung tuberculosis case at adult in Puskesmas Tuan-Tuan Ketapang region which are knowledge level $(p=0,026 ; R R=1,857 ; \mathrm{Cl}: 1,062-3,446)$ and smoking habit $(p=0,011 ; R R=2,407 ; \mathrm{Cl}: 1,118-5,186)$. From the result of multivariate analysis variable that is most dominant related lung tuberculosis case at adult in Puskesmas Tuan-Tuan Ketapang region is smoking habit with significant value 0,012 .

Conclusion: Statistically, there was relationship between knowledge level and smoking habit with lung tuberculosis case at adult in Puskesmas Tuan-Tuan Ketapang region. There is no relationship between economic status with lung tuberculosis case at adult in Puskesmas Tuan-Tuan Ketapang region. The most dominant variable that is related to lung tuberculosis case at adult in Puskesmas Tuan-Tuan Ketapang region is smoking habit.
\end{abstract}

Keyword: knowledge, economics status, smoking habit, lung tuberculosis at adult.

\section{PENDAHULUAN}

Tuberkulosis adalah penyakit menular langsung yang disebabkan oleh kuman TB (Mycobacterium tuberculosis). Sebagian besar kuman TB menyerang paru, tetapi dapat juga mengenai organ tubuh lainnya. Bakteri ini berbentuk batang, mempunyai sifat khusus yaitu tahan terhadap asam pada pewarnaan sehingga dikenal juga sebagai bakteri tahan asam (BTA).

Mycobacterium tuberculosis telah menginfeksi sepertiga penduduk dunia. Di negara maju diperkirakan terdapat 10 hingga 20 kasus di antara 100.000 penduduk, sedangkan angka kematian berkisar antara 1 hingga 5 kematian per 100.000 penduduk. Sementara di Afrika diperkirakan mencapai 165 kasus baru diantara 100.000 penduduk, dan di Asia 110 diantara 100.000 penduduk. World Health Organization (WHO) dalam Annual Report on Global TB Control 2003 menyatakan 
terdapat 22 negara dikategorikan sebagai high burden countries terhadap tuberkulosis, termasuk Indonesia. Di Indonesia penyakit TB paru masih menjadi masalah kesehatan masyarakat. Hasil Survei Kesehatan Rumah Tangga (SKRT) tahun 2001 menunjukkan bahwa tuberkulosis menduduki ranking ketiga sebagai penyebab kematian setelah sistem sirkulasi dan sistem pernafasan. Secara umum diperkirakan setiap 100.000 penduduk Indonesia terdapat 130 penderita baru TB paru BTA positif.

Berdasarkan Profil Kesehatan Kabupaten Ketapang tahun 2007 bahwa prevalensi penyakit tuberkulosis paru hingga akhir tahun 2005 diperkirakan masih 1,5 persen sedangkan prevalensi nasional 2,1/1000 penduduk. Oleh sebab itu penyakit tuberkulosis paru di Kabupaten Ketapang masih merupakan masalah kesehatan yang diprioritaskan oleh Dinas Kesehatan Kabupaten Ketapang. Hal ini dikarenakan penyakit tuberkulosis paru masih ditemukan di beberapa Puskesmas. Dari semua puskesmas yang ada di Ketapang, Puskesmas Tuan-Tuan mempunyai penderita tuberkulosis paru yang terbanyak yaitu 98 orang. Puskesmas Tuan-Tuan memiliki wilayah kerja 10 desa. Lingkup penyebab masalah penyakit tuberkulosis paru di Puskesmas Tuan-Tuan ini sangat multi faktor seperti masih rendahnya tingkat sosial ekonomi masyarakat, tingginya tingkat kebiasaan merokok dan kurangnya pemahaman/pengetahuan tentang penyakit TB paru.

Berdasarkan penjelasan di atas dapat ditarik dugaan bahwa masih banyaknya faktor-faktor risiko yang menyebabkan terjadinya tuberkulosis paru. Oleh karena itu, penulis tertarik untuk melakukan penelitian tentang hubungan tingkat pengetahuan, status ekonomi dan kebiasaan merokok dengan kejadian tuberkulosis paru pada orang dewasa di Kabupaten Ketapang Kalimantan Barat.

\section{METODE PENELITIAN}

Penelitian ini merupakan penelitian studi observasional dengan menggunakan rancangan penelitian cross sectional. Populasi dalam penelitian ini adalah semua penderita yang tercatat di dokumen P2M Puskesmas Tuan-Tuan Kabupaten Ketapang Kalimantan Barat pada bulan Januari 2009 sampai April 2009, sedangkan sampelnya menggunakan tekhnik totality sampling yang berjumlah 84 orang diambil dari seluruh populasi dengan kriteria penelitian.

Alat dalam penelitian ini adalah kuesioner. Kuesioner digunakan untuk memperoleh informasi dari variabel-variabel yang diteliti. Pengolahan data dilakukan dengan bantuan komputer dengan program SPSS. Analisis data meliputi analisis univariat, bivariat dan multivariat. Adapun langkah-langkah dalam analisis penelitian ini adalah:

a. Analisis univariat yaitu secara deskriptif dengan menggunakan tabel distribusi frekuensi.

b. Analisis bivariat yaitu secara analitik untuk mengetahui hubungan antara dua variabel dengan uji beda proporsi (chi-square) dan melihat besarnya risiko dengan Relative Risk (RR).

c. Analisis multivariat yaitu digunakan untuk mengetahui adanya hubungan variabel yang paling kuat dan menentukan hubungan antara tiga variabel dengan menggunakan regresi logistik.

\section{HASIL DAN PEMBAHASAN}

\section{A. Hasil Penelitian}

KES MAS Vol. 5, No. 3, September 2011: 162-232 
Tabel 1. Hasil Perhitungan Analisis Bivariat Masing-Masing Variabel Bebas dengan Kejadian Tuberkulosis Paru Pada Orang Dewasa di Wilayah Kerja Puskesmas Tuan-Tuan Kabupaten Ketapang Kalimantan Barat Tahun 2009

\begin{tabular}{llll}
\hline Variabel Bebas & $R R$ & $\mathrm{Cl}$ & $\mathrm{P}$ value \\
\hline Tingkat Pengetahuan & 1,857 & $1,062-3,446$ & 0,026 \\
\hline Status Ekonomi & 1,655 & $0,917-2,985$ & 0,082 \\
\hline Kebiasaan Merokok & 2,407 & $1,118-5,186$ & 0,011 \\
\hline
\end{tabular}

Tabel 1 menunjukkan bahwa dari tiga variabel yang diteliti, variabel yang bermakna secara statistik sebagai faktor kejadian tuberkulosis paru pada orang dewasa adalah tingkat pengetahuan dan kebiasaan merokok sedangkan status ekonomi tidak bermakna secara statistik.

Berdasarkan hasil analisis bivariat menunjukkan bahwa adanya hubungan yang bermakna antara tingkat pengetahuan dengan kejadian tuberkulosis paru pada orang dewasa dengan nilai $p=0,026<\alpha=0,05$. Hasil uji statistik diperoleh nilai $\mathrm{RR}=1,857$ artinya bahwa responden yang memiliki tingkat pengetahuan rendah akan meningkatkan risiko untuk terkena penyakit TB paru sebesar 1,857 kali lebih besar dibandingkan dengan responden yang memiliki tingkat pengetahuan tinggi. Tidak ada hubungan yang bermakna secara statistik antara status ekonomi dengan kejadian tuberkulosis paru pada orang dewasa dengan nilai $p=0,082>\alpha=0,05$. Akan tetapi secara biologi bermakna karena diperoleh nilai $R R=1,655$ artinya bahwa responden yang memiliki status ekonomi rendah akan meningkatkan risiko untuk terkena penyakit TB paru sebesar 1,655 kali lebih besar dibandingkan dengan responden yang memiliki status ekonomi tinggi. Ada hubungan yang bermakna antara kebiasaan merokok dengan kejadian tuberkulosis paru pada orang dewasa dengan nilai $p=0,011<\alpha=0,05$. Hasil uji statistik diperoleh nilai $\mathrm{RR}=2,407$ artinya bahwa responden yang memiliki kebiasaan merokok akan meningkatkan risiko untuk terkena penyakit TB paru sebesar 2,407 kali lebih besar dibandingkan dengan responden yang tidak memiliki kebiasaan merokok.

Tabel 2. Hasil Analisis Multivariat Antara Variabel yang Bermakna dengan Kejadian Tuberkulosis Paru Pada Orang Dewasa di Wilayah Kerja PuskesmasTuan-Tuan Kabupaten Ketapang Kalimantan Barat 2009

\begin{tabular}{|c|c|c|c|c|c|c|}
\hline & & B & Wald & $\mathrm{df}$ & Sig. & $\operatorname{Exp}(B)$ \\
\hline \multirow[t]{3}{*}{ Step $1^{a}$} & pengetahuan & 1.095 & 5.040 & 1 & .025 & 2.991 \\
\hline & merokok & 1.386 & 6.328 & 1 & .012 & 3.999 \\
\hline & Constant & -3.013 & 7.398 & 1 & .007 & .049 \\
\hline
\end{tabular}

Tabel 2 di atas menunjukkan bahwa tingkat signifikan hubungan dari 2 variabel bebas yaitu tingkat pengetahuan dan kebiasaan merokok dengan kejadian TB Paru pada orang dewasa. Tabel di atas menunjukkan bahwa tingkat pengetahuan dengan nilai signifikan $(0,025)$, sedangkan kebiasaan merokok dengan nilai signifikan $(0,012)$. Variabel bebas yang nilai signifikan mendekati atau kurang dari nilai á $=0,05$ maka variabel tersebut adalah 
variabel yang paling dominan berhubungan dengan variabel terikat. Berdasarkan hasil analisis multivariat menunjukkan bahwa kebiasaan merokok yang paling dominan berhubungan dengan kejadian TB Paru pada orang dewasa dengan nilai signifikan 0,012.

\section{B. Pembahasan}

Berdasarkan hasil penelitian tentang hubungan antara tingkat pengetahuan, status ekonomi dan kebiasaan merokok dengan kejadian tuberkulosis paru pada orang dewasa di Kabupaten Ketapang Kalimantan Barat, dari tingkat pengetahuan ternyata memperoleh nilai $p=0,026<0,05$ berarti ada hubungan yang bermakna antara tingkat pengetahuan dengan kejadian tuberkulosis paru pada orang dewasa. Besarnya risiko dari hasil output diperoleh nilai $R R=1,857$ lebih besar dari 1 (95\% $\mathrm{Cl}$ : 1,062-3,446) yang nilainya tidak mencakup angka 1 , artinya bahwa orang dengan tingkat pengetahuan yang rendah akan meningkatkan risiko untuk terkena TB sebesar 1,857 kali lebih besar dari orang yang memiliki tingkat pengetahuan yang tinggi. Hasil penelitian ini sejalan dengan hasil penelitian Purwanto (2003) ${ }^{1}$ yang menyatakan ada hubungan antara tingkat pengetahuan dengan kejadian tuberkulosis paru.

Pada variabel status ekonomi diperoleh nilai $p=0,082>0,05$ dan nilai $\mathrm{Cl}: 0,917-$ 2,985 (mencakup angka 1), berarti dapat disimpulkan bahwa secara statistik hubungan antara tingkat ekonomi tidak bermakna atau tidak ada hubungan antara status ekonomi dengan kejadian TB Paru pada orang dewasa. Hasil dari penelitian ini tidak sesuai dengan teori yang ada. Hal ini diduga disebabkan oleh fakta yang memperlihatkan bahwa tingkat ekonomi responden antara tingkat ekonomi rendah dan tinggi yang hampir sama menyebabkan tingkat ekonomi tidak ada hubungan dengan kejadian tuberkulosis paru pada orang dewasa di Wilayah Kerja Puskesmas Tuan-Tuan Kabupaten Ketapang Kalimantan Barat. Kejadian tuberkulosis paru pada orang dewasa di Wilayah Kerja Puskesmas Tuan-Tuan Kabupaten Ketapang Kalimantan Barat disebabkan oleh variabel lain yang dominan dalam penelitian ini atau oleh variabel lain yang tidak terjaring dalam penelitian ini. Hasil dari penelitian ini tidak sejalan dengan Achmadi (2005) ${ }^{2}$, menyebutkan bahwa 90 persen penderita TBC didunia menyerang kelompok dengan sosial ekonomi lemah atau miskin. Hasil penelitian Purwanto (2003) ${ }^{1}$ juga menyebutkan bahwa risiko terkena TB paru pada orang dengan pendapatan kurang dari UMR adalah 5,606 kali lebih besar dari pada orang dengan pendapatan lebih dari UMR.

Pada variabel kebiasaan merokok diperoleh nilai $p=0,011<0,05$ berarti ada hubungan yang bermakna antara kebiasaan merokok dengan kejadian tuberkulosis paru pada orang dewasa. Besarnya risiko dari hasil output diperoleh nilai $\mathrm{RR}=2,407$ lebih besar dari $1(95 \% \mathrm{Cl}: 1,118-5,186)$ yang nilainya tidak mencakup angka 1, artinya bahwa orang yang mempunyai kebiasaan merokok akan meningkatkan risiko untuk terkena TB sebesar 2,407 kali lebih besar dari orang yang tidak mempunyai kebiasaan merokok. Hasil penelitian ini sejalan dengan penelitian Mahmudah (2003) ${ }^{3}$ yang menyebutkan bahwa ada hubungan secara bermakna kebiasaan merokok dengan kejadian tuberkulosis paru dan memiliki risiko terkena TB sebesar 4,3 kali dibandingkan dengan orang yang tidak merokok.

Hasil analisis multivariat (regresi logistic) menunjukkan bahwa dari ke tiga variabel bebas yang diteliti ada 2 variabel yang hasil analisis bivariat menunjukkan secara statistik bermakna. Variabel tersebut yaitu tingkat pengetahuan dengan nilai

KES MAS Vol. 5, No. 3, September 2011: 162-232 
signifikan $(0,025)$ dan kebiasaan merokok dengan nilai signifikan $(0,012)$. Variabel bebas yang nilai signifikan mendekati atau kurang dari nilai á=0,05 maka variabel tersebut adalah variabel yang paling dominan berhubungan dengan variabel terikat. Dari hasil analisis multivariat menunjukkan bahwa kebiasaan merokok merupakan variabel yang paling dominan berhubungan dengan kejadian TB Paru pada orang dewasa dengan nilai signifikan 0,012 . Hal ini diterima karena kebiasaan merokok sangat berpengaruh terhadap tuberkulosis paru.

\section{SIMPULAN DAN SARAN}

\section{A. Simpulan}

1) Ada hubungan antara tingkat pengetahuan dengan kejadian Tuberkulosis Paru pada orang dewasa di Wilayah Kerja Puskesmas Tuan-Tuan Kabupaten Ketapang Kalimantan Barat ( $p=0,026 ; \mathrm{RR}=1,857 ; \mathrm{Cl}: 1,062-3,446)$.

2) Tidak ada hubungan antara status ekonomi dengan kejadian Tuberkulosis Paru pada orang dewasa di Wilayah Kerja Puskesmas Tuan-Tuan Kabupaten Ketapang Kalimantan Barat ( $p=0,082 ; \mathrm{RR}=1,655 ; \mathrm{Cl}: 0,917-2,985)$.

3) Ada hubungan antara kebiasaan merokok dengan kejadian Tuberkulosis Paru pada orang dewasa di Wilayah Kerja Puskesmas Tuan-Tuan Kabupaten Ketapang Kalimantan Barat $(p=0,011$; RR=2,407; Cl: 1,118-5,186).

4) Faktor yang paling dominan mempengaruhi kejadian TB Paru pada orang dewasa di Wilayah Kerja Puskesmas Tuan-Tuan Kabupaten Ketapang Kalimantan Barat adalah kebiasaan merokok $(p=0,012$; $R R=3,999)$.

\section{B. Saran}

1) Bagi Puskesmas Tuan-Tuan Kabupaten Ketapang Kalimantan Barat

a) Perlu adanya upaya peningkatan komunikasi, informasi dan edukasi tentang bahaya merokok terhadap kesehatan, khususnya dalam kaitannya dengan Tuberkulosis Paru

b) Perlu dilakukan peningkatan pengetahuan tentang penyakit Tuberkulosis Paru kepada masyarakat dengan cara penyuluhan agar masyarakat lebih paham dan bisa melakukan tindakan pencegahan.

c) Perlu dilakukan database penderita tuberkulosis paru dan penyakit menular lainnya yang terus diperbarui dan lengkap penulisan alamatnya.

2) Bagi Tenaga Kesehatan

Perlunya dilakukan upaya kunjungan rumah ke penderita oleh petugas Puskesmas untuk mengetahui kepatuhan minum obat, kemajuan penyembuhan dan pencegahan penularan terhadap keluarga.

3) Bagi Peneliti Lain

Perlunya dilakukan penelitian lebih lanjut tentang pengetahuan, status ekonomi dan kebiasaan merokok dengan kejadian tuberkulosis paru dengan menggunakan metode dan instrument yang lebih lengkap, misalnya dengan pedoman wawancara mendalam atau rancangan penelitian cohort study. 


\section{DAFTAR PUSTAKA}

1. Purwanto, H., Faktor yang Berpengaruh Terhadap Kejadian Tuberkulosis Paru di Desa Tanggul Kulon Kecamatan Tanggul Kabupaten Jember. http://digilib.unej.ac.id, diakses pada tanggal 4 Juni 2009, Yogyakarta. 2003

2. Achmadi, U. F., Manajemen Penyakit Berbasis Wilayah, Penerbit Buku Kompas, Jakarta. 2005

3. Mahmudah, Hubungan Kebiasaan Merokok dengan Kejadian Tuberkulosis Paru di Kecamatan Comal dan Kecamatan Ulujami Kabupaten Pemalang: http:// www.fkm.undip.ac.id, diambil pada tanggal 30 Maret 2009, Yogyakarta. 2003 